$\begin{array}{rr}\text { FIT(PATOLOGI } & \text { Volume } 11, \text { Nomor 1, Februari 2015 } \\ \text { I N DONES IA } & \text { Halaman 9-13 } \\ \text { ISSN: } 0215-7950 & \text { DOI: } 10.14692 / \text { jif.13.1.9 }\end{array}$

\title{
Penapisan Cendawan Antagonis Indigenos Rizosfer Jahe dan Uji Daya Hambatnya terhadap Fusarium oxysporum f. sp. zingiberi
}

\author{
Screening for Antagonistic Fungi Indigenous to Ginger Rhizosphere \\ and Evaluation of Their Inhibitory Effect on the Growth \\ of Fusarium oxysporum f. sp. zingiberi
}

Nurbailis*, Winarto, Afriani Panko

Universitas Andalas, Padang 25163

\begin{abstract}
ABSTRAK
Penyakit busuk rimpang jahe yang disebabkan oleh Fusarium oxysporum f. sp. zingiberi tergolong sulit dikendalikan karena bersifat tular tanah dan dapat membentuk klamidospora sebagai struktur bertahan. Tujuan penelitian ialah mendapatkan isolat cendawan antagonis yang berasal dari rizosfer jahe yang berpotensi menghambat pertumbuhan $F$. oxysporum f. sp. zingiberi. Cendawan pada rizosfer jahe diisolasi dan diuji daya antagonisnya menggunakan metode biakan ganda. Cendawan yang mampu menghambat $F$. oxysporum f. sp. zingiberii diidentifikasi. Sebanyak 11 isolat cendawan berhasil diisolasi dari rizosfer tanaman jahe, dan 9 isolat di antaranya berpotensi menghambat pertumbuhan $F$. oxysporum f. sp. zingiberii. Aktivitas antibiosis ditunjukkan oleh 9 isolat cendawan, yaitu AB4, GC1, BB1, AB1, $\mathrm{AB} 2, \mathrm{~K} 12, \mathrm{GC} 3, \mathrm{~K} 11, \mathrm{GC} 2$, dan isolat AB2, BB1, serta K11 menunjukkan kemampuan kompetisi. Berdasarkan pengamatan morfologi konidium diketahui bahwa cendawan antagonis tersebut terdiri atas Penicillium spp. (4 isolat), Trichoderma spp. (3 isolat), and Aspergillus spp. (2 isolat).
\end{abstract}

Kata kunci: Aspergillus, busuk rimpang, Penicillium, Trichoderma

\begin{abstract}
Ginger rot disease caused by Fusarium oxysporum f. sp. zingiberi is difficult to control because the pathogen is soil borne and is able to form clamidospore as resting structure. The aim of this study was to obtain indigenous antagonistic fungi from ginger rhizosphere which is potential for suppressing the growth of $F$. oxysporum f. sp. zingiberi. Fungi isolated from ginger rhizosphere were subjected for antagonism assay using dual culture method. Fungi isolates showed capability to inhibit $F$. oxysporum f. sp. zingiberii were then identified based on morphology characters. Eleven isolates were successfully isolated, but only 9 isolates showed the potentials of suppressing the growth of $F$. oxysporum $\mathrm{f}$. sp. zingiberi. All 9 isolates i.e. AB4, GC1, BB1, AB1, AB2, K12, GC3, K11 and GC2 had antibiosis activity, and 3 isolates among them i.e. AB2, BB1 and K11 showed competition mechanism. Based on morphology characters the isolates were identified as Penicillium spp. (4 isolates), Trichoderma spp. (3 isolates), and Aspergillus spp. (2 isolates).
\end{abstract}

Key words: Aspergillus, ginger rot, Penicillium, Trichoderma

*Alamat penulis korespondensi: Jurusan Hama dan Penyakit Tumbuhan, Fakultas Pertanian, Universitas Andalas, Padang, Kampus Limau Manis, Padang 25163

Tel: 0751-7059087, Faks: 0751-72702, Surel: nurbailisjamarun@yahoo.co.id 


\section{PENDAHULUAN}

Penyakit busuk rimpang yang disebabkan oleh Fusarium oxysporum f. sp. zingiberi merupakan salah satu penyakit penting pada jahe. Penyakit ini sudah tersebar pada semua daerah penanaman jahe di Indonesia. Djiwanti (2012) melaporkan bahwa tingkat serangan penyakit busuk rimpang pada jahe di Magelang mencapai 67\%.

Beberapa usaha pengendalian penyakit busuk rimpang pada jahe yang telah dilakukan selama ini belum memberikan hasil yang memuaskan. Oleh sebab itu, alternatif pengendalian yang lebih efektif dan ramah lingkungan yaitu dengan menerapkan pengendalian hayati diperlukan. Keberhasilan pemanfaatan mikroorganisme yang bersifat antagonis untuk pengendalian berbagai patogen tanaman telah banyak dilaporkan (Sudantha et al. 2011; Alwanthani dan Perveen 2012).

Beberapa cendawan antagonis seperti Aspergillus niger, Penicillium citrinun, Penicillium sp. dan Trichoderma harzianum dapat menghambat pertumbuhan $F$. oxysporum f. sp. lycopersici penyebab penyakit layu pada tanaman tomat (Alwanthani dan Perveen 2012). Sudantha et al. (2011) melaporkan bahwa cendawan antagonis Trichoderma spp. efektif menghambat pertumbuhan cendawan patogen F. oxysporum f. sp. cubenses secara in vitro dengan mekanisme kompetisi, mikoparasit dan antibiosis. Russel et al. (2004) dan Dimitrios et al. (2012) menyatakan Aspergillus spp. menghasilkan mikotoksin yang berguna untuk menghambat pertumbuhan patogen

Penelitian ini dilakukan untuk mendapatkan isolat cendawan antagonis indigenos rizosfer jahe yang berpotensi menekan pertumbuhan $F$. oxysporum f. sp. zingiberi penyebab penyakit busuk rimpang jahe.

\section{BAHAN DAN METODE}

\section{Pengambilan Sampel Tanah}

Sampel tanah diambil dari beberapa daerah penanaman jahe yang terserang penyakit busuk rimpang di Kabupaten Solok, Provinsi
Sumatera Barat. Penetapan lokasi pengambilan sampel di lapangan ditentukan dengan metode acak bertingkat. Pertama dipilih 2 kecamatan, selanjutnya pada tiap kecamatan dipilih 2 nagari, dan masing-masing nagari diambil 1 hamparan pertanaman jahe. Sampel tanah diambil dari daerah perakaran dan permukaan rimpang tanaman pada rumpun tanaman jahe yang sehat di daerah yang terserang penyakit busuk rimpang. Sampel tanah pada masingmasing hamparan diambil dari 5 titik yang ditentukan secara acak dengan pola diagonal.

\section{Isolasi Cendawan Antagonis}

Isolasi cendawan antagonis dilakukan dengan metode pengenceran berseri. Sampel tanah diambil sebanyak $10 \mathrm{~g}$ dimasukkan ke dalam $100 \mathrm{~mL}$ akuades steril dalam tabung erlenmeyer kemudian dihomogenkan selama 30 menit. Suspensi tanah yang diperoleh diencerkan sampai $10^{-3}$ dan $10^{-4}$, kemudian disebar pada medium potato dextrose agar (PDA), selanjutnya diinkubasi pada suhu kamar selama 3-5 hari. Tiap koloni cendawan yang tumbuh diisolasi pada medium PDA dan selanjutnya dibuat biakan murni dengan teknik spora tunggal.

\section{Persiapan Isolat F. oxysporum f. sp. zingiberi}

Cendawan patogen diisolasi dari tanaman jahe yang bergejala busuk rimpang menggunakan metode moist chamber. Rimpang jahe yang terinfeksi dibersihkan kemudian dipotong dengan ukuran $\pm 1 \mathrm{~cm}$ dengan membawa bagian tanaman sakit dan sehat. Potongan rimpang ini disterilkan permukaannya dengan alkohol $70 \%$, selanjutnya bagian tanaman dimasukkan ke dalam cawan petri yang telah dilapisi 3 lembar kertas saring yang telah dilembapkan, kemudian diinkubasi selama 48 jam. Miselium yang tumbuh, diisolasi ke medium PDA. F. oxysporum f. sp. zingiberi diisolasi dengan teknik spora tunggal untuk mendapatkan biakan murni. Identifikasi dilakukan dengan mengamati bentuk morfologi cendawan secara makroskopi dan mikroskopi didasarkan pada kunci identifikasi Leslie dan Summerell (2006). 


\section{Uji Daya Antagonis}

Pengujian daya antagonis cendawan hasil isolasi terhadap $F$. oxysporum f. sp. zingiberi dilakukan dengan metode biakan ganda. Metode ini digunakan untuk mengamati kemampuan isolat cendawan antagonis indigenos dalam menekan pertumbuhan F. oxysporum f. sp. zingiberi. Metode ini dilakukan dengan cara menumbuhkan potongan biakan cendawan antagonis dan $F$. oxysporum f. sp. zingiberi dalam satu cawan petri yang telah berisi PDA dengan jarak $4 \mathrm{~cm}$ antara kedua potongan.

Pengujian daya antagonis disusun menggunakan rancangan acak lengkap, dengan perlakuan berupa isolat cendawan yang diisolasi dari rizosfer jahe (11 isolat) dan masing-masing perlakuan diulang 4 kali. Data hasil pengamatan dianalisis dengan uji Duncan pada taraf 5\%.

Pengamatan dilakukan terhadap kemampuan penghambatan dan antibiosis. Kemampuan penghambatan cendawan antagonis diukur sejak hari ke-2 setelah isolasi sampai koloni kedua cendawan bertemu. Persentase penghambatan dihitung menggunakan rumus dari Fokkema dan Skidmore (1976):

$$
\mathrm{P}=\frac{\mathrm{r}_{1}-\mathrm{r}_{2}}{\mathrm{r}_{1}} \times 100 \% \text {, dengan }
$$

$\mathrm{P}$, kemampuan penghambatan oleh cendawan antagonis; $\mathrm{r}_{1}$, jari-jari koloni $F$. oxysporum yang menjauhi cendawan antagonis; $\mathrm{r}_{2}$, jari-jari koloni $F$. oxysporum yang mendekati cendawan antagonis.

Pengamatan mekanisme antibiosis didasarkan terhadap lebar daerah yang tidak ditumbuhi oleh cendawan (zona bening), yaitu dengan mengukur lebar bagian bening yang terbentuk di antara koloni kedua cendawan tersebut.

\section{Identifikasi Isolat Cendawan}

Identifikasi dilakukan terhadap isolat cendawan yang berpotensi menekan pertumbuhan $F$. oxysporum dengan melakukan pengamatan makroskopi dan mikroskopi. Pengamatan makroskopi dilakukan secara visual terhadap warna koloni, bentuk dan arah pertumbuhan koloni. Pengamatan mikroskopi meliputi bentuk konidium, warna konidium, dan ciri-ciri spesifik dari masing-masing cendawan antagonis tersebut. Identifikasi didasarkan pada kunci identifikasi dari Barnet dan Hunter (1972), Kulwan et al. (1991), dan Watanabe (2002).

\section{HASIL}

Sebanyak 11 isolat cendawan yang beragam berhasil diisolasi dari rizosfer tanaman jahe. Uji antagonisme terhadap $F$. oxysporum f. sp. zingiberi menunjukkan bahwa isolat yang mampu menghambat pertumbuhan $F$. oxysporum f. sp. zingiberri hanya isolat $\mathrm{AB} 2, \mathrm{BB} 1$, dan $\mathrm{KI} 1$, sedangkan zona bening terbentuk pada perlakuan dengan isolat $\mathrm{AB} 4, \mathrm{GC} 1, \mathrm{BB} 1, \mathrm{AB} 1, \mathrm{AB} 2, \mathrm{~K} 12, \mathrm{GC} 3$, K11 dan GC2 (Gambar 1).

Kemampuan penghambatan isolat $\mathrm{AB} 2$, BB1, dan KI1 terhadap F.oxysporum $\mathrm{f}$. sp. zingiberi tidak berbeda nyata. Lebar zona bening yang terbentuk berbeda nyata antarisolat (Tabel 1).

Berdasarkan pengamatan morfologi konidium diketahui bahwa isolat cendawan antagonis yang berasal dari rizosfer tanaman jahe terdiri atas Trichoderma spp. (3 isolat), Penicillium spp. (4 isolat), dan Aspergillus spp. (2 isolat) (Tabel 1).

\section{PEMBAHASAN}

Sebelas isolat cendawan yang diisolasi dari rizosfer tanaman jahe menunjukkan keragaman cendawan yang berasal dari rizosfer tanaman jahe. Mekanisme antagonisme dari cendawan antagonis dapat berupa pertumbuhan yang lebih cepat dari pertumbuhan cendawan patogen atau kemampuannya menghasilkan sesuatu senyawa yang dapat menghambat pertumbuhan patogen. Sudantha et al. (2011) melaporkan bahwa penghambatan pertumbuhan cendawan patogen $F$. oxysporum f. sp. cubenses oleh cendawan saprob Trichoderma spp. disebabkan oleh kemampuan cendawan antagonis berkompetisi dengan cendawan patogen, mampu menghasilkan senyawa yang dapat menghambat pertumbuhan 

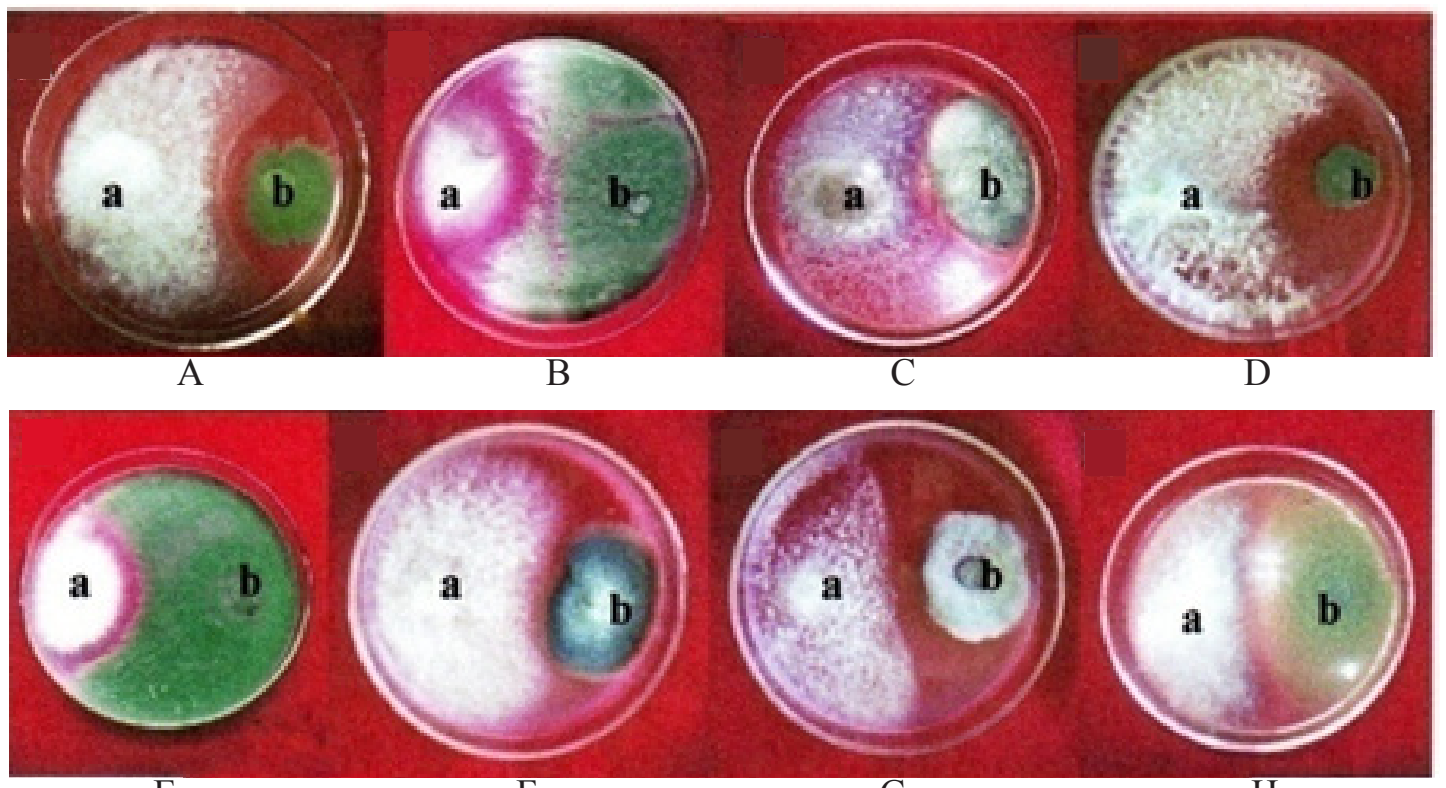

$\mathrm{E}$ $\mathrm{F}$

G

$\mathrm{H}$

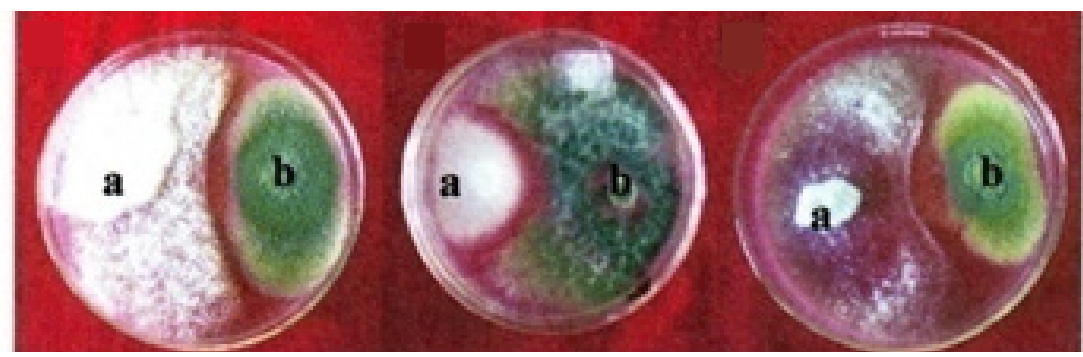

I

$\mathrm{K}$

Gambar 1 Pengujian antagonisme isolat-isolat cendawan indigenos rizosfer jahe terhadap $F$. oxysporum f. sp. zingiberi. a, cendawan $F$. oxysporum f. sp. zingiberi; b, isolat cendawan antagonis: $\mathrm{A}$, isolat $\mathrm{AB} 1 ; \mathrm{B}$, isolat $\mathrm{AB} 2 ; \mathrm{C}$, isolat $\mathrm{AB} 3 ; \mathrm{D}$, isolat $\mathrm{AB} 4$; $\mathrm{E}$, isolat $\mathrm{BB} 1 ; \mathrm{F}$, isolat $\mathrm{BB} 2$; $\mathrm{G}$, isolat $\mathrm{GC} 1$; $\mathrm{H}$, isolat $\mathrm{GC} 2$; I, isolat $\mathrm{GC} 3$; $\mathrm{J}$, isolat $\mathrm{GC} 1$ dan; $\mathrm{K}$, isolat $\mathrm{GC} 2$.

Tabel 1 Lebar zona bening dan kemampuan penghambatan isolat cendawan indigenos rizosfer jahe terhadap $F$. oxysporum f. sp. zingiberi

\begin{tabular}{|c|c|c|c|}
\hline \multicolumn{2}{|c|}{ Isolat cendawan antagonis } & \multirow{2}{*}{$\begin{array}{l}\text { Rata-rata lebar zona bening } \\
\qquad(\mathrm{mm})\end{array}$} & \multirow{2}{*}{$\begin{array}{c}\text { Kemampuan penghambatan } \\
(\%)\end{array}$} \\
\hline$\overline{\text { Kode }}$ & Genus & & \\
\hline$\overline{\mathrm{AB} 4}$ & Penicillium spp. & $7.3 \mathrm{a}$ & TM \\
\hline $\mathrm{GC} 1$ & Aspergillus spp. & $7.0 \mathrm{a}$ & TM \\
\hline BB1 & Trichoderma spp. & $6.8 \mathrm{ab}$ & $35.5 \mathrm{a}$ \\
\hline $\mathrm{AB} 1$ & Penicillium spp. & $6.5 \mathrm{ab}$ & $\mathrm{TM}$ \\
\hline AB2 & Trichoderma spp. & $6.0 \mathrm{ab}$ & $43.3 \mathrm{a}$ \\
\hline KI2 & Penicillium spp. & $6.0 \mathrm{ab}$ & TM \\
\hline $\mathrm{GC} 3$ & Penicillium spp. & $5.0 \mathrm{~b}$ & TM \\
\hline KI1 & Trichoderma spp. & $2.3 \mathrm{c}$ & $46.3 \mathrm{a}$ \\
\hline $\mathrm{GC} 2$ & Aspergillus spp. & $2.0 \mathrm{c}$ & $\mathrm{TM}$ \\
\hline
\end{tabular}

Angka yang diikuti huruf yang sama pada kolom yang sama tidak berbeda nyata pada taraf 5\%.

TM, tidak ada penghambatan

patogen dan bersifat mikoparasit terhadap cendawan patogen sehingga pertumbuhan cendawan $F$. oxysporum f. sp. cubense menjadi terhambat.
Dari hasil identifikasi diketahui bahwa 3 isolat cendawan yang berasal dari rizosfer tanaman jahe yang mampu berkompetisi dengan $F$. oxysporum termasuk ke dalam genus 
Trichoderma. Cendawan Trichoderma tumbuh lebih cepat dibandingkan dengan $F$. oxysporum f. sp. zingiberi. Salah satu mekanisme Trichoderma spp. menghambat pertumbuhan Fusarium oxysporum f. sp. cubenses in vitro adalah kompetisi (Sudantha et al. 2011). Taj dan Kumar (2013) melaporkan bahwa T. viride merupakan spesies yang terbaik menekan pertumbuhan $F$. oxysporum f. sp. zingiberi dengan persentase penghambatan $88 \%$.

Zona bening yang terbentuk antara dua koloni cendawan disebabkan oleh adanya senyawa metabolit sekunder yang dihasilkan oleh koloni cendawan antagonis sehingga cendawan patogen tidak dapat tumbuh mendekati cendawan antagonis. Srinon et al (2006) melaporkan bahwa metabolit sekunder yang dihasilkan oleh T. hamatum WS01 dan Penicillium sp. WO1 berupa enzim selulase yang dapat menghambat pembentukan spora $F$. oxysporum f. sp. cucumeris dan F. oxysporum f. sp. licopersicy dengan mekanisme antibiosis. Dimitrios et al. (2012) menyatakan bahwa cendawan Aspergillus spp. menghasil zat antibiotik aflatoksin dan ochratoksin.

\section{DAFTAR PUSTAKA}

Alwanthani HA, Perveen K. 2012. Biological control of fusarium wilt of tomato by antagonistic fungi and cyanobacteria. Afr J Biotech. 11(5):1100-1105.

Barnet HL, Hunter BB. 1972. Ilustrated Genera of Imperfect Fungi. Third Edition. Minneapolis (US): Publishing Company.

Dimitrios I, Tsitsigiannis, Dimakopoulou M, Antaniou PP, Tjamos EC. 2012. Biological control strategies of mycotoxigenic fungi and associated mycotoxin in Mediteterranean basin crop. Phytopathol Mediterran. 51(1):158-174.

Djiwanti SR. 2012. Penyakit busuk rimpang menghambat usaha peningkatan produksi jahe di indonesia. Agroinovasi. No. 3472.

Fokkema, Skidmore AM. 1976. Interaction in relation to biological control of plant pathogens. Di dalam: Dickison $\mathrm{CH}$.
Preece TF, editor. Microbiology of Aerial Plant surfaces. New York (US): Academic Pr. hlm 507-527.

Kulwan SJT, Frisvad UT, Mathur SB. 1991. An Illustrated Manual on Identification of Some Seed Borne Aspergilli, Fusaria, Penicillia and Their Mycotoxins. Denmark (DK): Danish Government Institute of Seed Pathology for Developing Contries.

Leslie JF, Summerell BA. 2006. The Fusarium Laboratory Manual. Iowa (US): Blackwell. DOI: http://dx.doi. org/10.1002/9780470278376.

Russel R, Paterson M, Vanancio A, Lima N, 2004. Solution to penicillium taxonomy crucial to mycotoxin research and health. Res Microbiol. 155:507-513. DOI: http:// dx.doi.org/10.1016/j.resmic.2004.04.001.

Srinon W, Chuncheen K, Jirattiwarutkul K, Soytong K, Kanotmedhakul S. 2006. Efficasies of antagonistic fungi againts fusarium wilt disease of cucumber and tomato and the assay of its enzyme activity. J Agric Tech. 2(2):191-201.

Sudantha IM, Kusnarta IGM, Sudana IN. 2011. Uji antagonisme beberapa jenis cendawan saprofit terhadap cendawan Fusarium oxysporum f. sp. cubense penyebab penyakit layu pada tanaman pisang serta potensinya sebagai agens pengurai serasah. Agroteksos. 21(2-3):106-109.

Taj A, Kumar VBS. 2013. Sensitivity of Fusarium oxysporum f. sp. zingiberi causing ginger yellow against antagonist and fungicide. J Environ Ecol. 31(2A):663666.

Watanabe T. 2002. Pictorial Atlas of Soil and Seed Fungi. Morphologies of Culture Fungi and Key to Spesies. Ed ke-2. New York (US): CRC Press. DOI: http://dx.doi. org/10.1201/9781420040821. 